\title{
Spermatozoa stimulate prostaglandin synthesis and secretion in bovine oviductal epithelial cells
}

\author{
Suranga P Kodithuwakku, Akio Miyamoto ${ }^{1}$ and Missaka P B Wijayagunawardane \\ Department of Animal Science, University of Peradeniya, Peradeniya 20400, Sri Lanka and ${ }^{1}$ Graduate School of \\ Animal and Food Hygiene, Obihiro University of Agriculture and Veterinary Medicine, Obihiro 080-8555, Japan \\ Correspondence should be addressed to M P B Wijayagunawardane; Email: missakaw@pdn.ac.Ik
}

\begin{abstract}
The dynamic action of oviductal secretory compounds on spermatozoa function is well documented. In contrast, the effect of spermatozoa on oviductal function remains poorly characterized. Previously, our lab and others have shown that prostaglandin (PG), together with other vasoactive peptides, plays major roles in oviductal contractions and sperm transport. We therefore examined the effect of spermatozoa on the production of PG by cow oviductal epithelial cells (OEC). A bovine spermatozoa-OEC co-culture system was utilized for this purpose. OECs in the second passage were co-cultured for $0,1,3,6,12$, and $24 \mathrm{~h}$ with six doses of motile, killed, or truncated spermatozoa heads (control; without spermatozoa, $10^{2}-10^{6}$ spermatozoa/ml medium). The levels of $\mathrm{PGE}_{2}$ and $\mathrm{PGF}_{2 \alpha}$ in the medium were measured using enzyme immunoassays. Messenger RNA expression of cyclooxygenase-2, PGF synthase (PGFS), and PGE synthase (PGES) was investigated using real-time RT-PCR. The results indicated that motile spermatozoa increased the secretion of PG by OEC as well as cellular expression of mRNA for cyclooxygenase, PGES, and PGFS in a dose- and time-dependent manner. A maximum three- to fivefold increased secretion of PG was observed with a dose of $10^{5}$ spermatozoa/ml after a 12-h co-incubation. Neither killed spermatozoa nor truncated spermatozoa heads stimulated oviductal biosynthesis and secretion of PG at any dose or time point observed. The results provide the first evidence that live spermatozoa in the oviduct up-regulate the local PG system, and thereby, enhance oviductal contractions. Thus, spermatozoa may bear a role in accelerating their own transport into the fertilization site.
\end{abstract}

Reproduction (2007) 133 1087-1094

\section{Introduction}

The oviduct provides an optimal environment for the final maturation of spermatozoa, capacitation, acrosomal reaction as well as the survival of spermatozoa in the oviduct until the fertilization process. The dynamic action of oviductal secretions on spermatozoa survival and function during the long sojourn in the oviduct is well documented. Oviduct secretions (Parrish et al. 1989, Ellington 1991, McNutt and Killian 1991, Killian 2004), including specific glycoproteins (Abe et al. 1995), bicarbonate ions, progesterone $\left(\mathrm{P}_{4}\right)$, and oviductin (Boatman 1997), provide an optimal environment for spermatozoa in the oviduct. In addition, bovine oviductal epithelial cells (BOECs) also produce prostaglandin $E_{2}\left(P E_{2}\right)$ and $P F_{2 \alpha}$ that are reported to be actively involved in the regulation of oviductal contractions (Wijayagunawardane et al. 2001b). Our recent studies revealed that locally produced peptides such as endothelin-1 (ET-1), tumor necrosis factor (TNF)- $\alpha$, angiotensin II (Ang II), antrial natriuretic peptide (ANP), and vascular endothelial growth factor (VEGF) stimulate
PG secretion and oviductal motility during the periovulatory period (Wijayagunawardane et al. 2001a, 2001b, 2003, 2005, Wijayagunawardane \& Miyamoto 2004b). These findings suggest that gamete transport in the cow oviduct is mediated by local vasoactive substances and cytokines, which reach their highest concentrations during the periovulatory stage.

Sperm-OEC interaction is highly specific, initiated by uncapacitated spermatozoa binding to OEC, and continued by the induction of capacitation (Fazeli et al. 1999). Bovine spermatozoa stimulate de novo protein synthesis in the bovine oviduct (Ellington et al. 1993), and in the mice oviduct, spermatozoa change the gene expression profiles (Fazeli et al. 2004) as well as the secretory proteome (Georgiou et al. 2005). However, the influence of spermatozoa directly on oviductal function remains poorly characterized. Thus, in the present study, we used capacitated spermatozoa and BOEC in a co-culture system to evaluate the effect of spermatozoa on the modulation of PG synthesis and secretion in the bovine oviduct. 


\section{Materials and Methods}

\section{Isolation and culture of cow OEC}

Oviducts from non-pregnant Holstein cows during the follicular phase were collected at a local slaughterhouse. The stage of the estrous cycle was identified according to the previous report (Wijayagunawardane et al. 1998) based on the morphology of the corpus luteum $(\mathrm{CL})$, uterine fluid and cervical mucus characteristics, and luteal $\mathrm{P}_{4}$ levels. The collected oviducts were transported to the laboratory in ice-cold Hanks' balanced salt solution (HBSS; Nissui pharmaceutical Co. Ltd, Tokyo, Japan).

The isolation and culture of BOEC were based on the method described previously (Wijayagunawardane et al. 1999a, 1999b). In brief, the surrounding connective tissues were trimmed from the oviduct, washed with HBSS, the oviductal lumen was flushed with $10 \mathrm{ml}$ HBSS, and the BOEC were mechanically dislodged by squeezing the oviduct gently while flushing them with $15 \mathrm{ml}$ HBSS. Then, the collected sheets of BOEC from several cows were pooled and washed twice with HBSS by centrifuging at $300 \mathrm{~g}$ for $10 \mathrm{~min}$ at $4{ }^{\circ} \mathrm{C}$. Thereafter, the cell pellet was suspended in $4 \mathrm{ml} \mathrm{HBSS}$, layered over $5 \mathrm{ml}$ percol, and centrifuged at $900 \mathrm{~g}$ for $20 \mathrm{~min}$ at $4{ }^{\circ} \mathrm{C}$. The cells in interphase were collected and washed twice with HBSS. The collected sheets of BOEC were cultured overnight in culture medium (Medium 199; HEPES modification; $0.85 \mathrm{~g} / \mathrm{l} \mathrm{NaHCO}_{3}, 60 \mathrm{mg} / \mathrm{l}$ penicillin, $100 \mathrm{mg} / \mathrm{l}$ streptomycin, and $56 \mathrm{mg} / \mathrm{l}$ ascorbic acid; Sigma Chemical Co.) supplemented with $5 \%$ fetal bovine serum (FBS; Bio Whittaker, Walkersville, MD, USA) at $38.5{ }^{\circ} \mathrm{C}$ in $5 \% \mathrm{CO}_{2}$ and $95 \%$ air. The BOECs in the suspension were taken, washed twice with HBSS, and trypsinized $(0.05 \%$ trypsin-EDTA; Amresco, Salon, $\mathrm{OH}$, USA) until single cells appeared. Subsequently, the BOECs were plated in six-well culture dishes (Nalge Nunc International, Roskilde, Denmark) and incubated in the culture medium supplemented with $5 \%$ FBS at $38.5{ }^{\circ} \mathrm{C}$ in $5 \% \mathrm{CO}_{2}$ and $95 \%$ air. After monolayer formation, cells were re-trypsinized and re-plated in sixwell culture dishes (Nalge Nunc International) at a density of $3 \times 10^{4} \mathrm{ml}$ and incubated at $38.5^{\circ} \mathrm{C}$ in $5 \%$ $\mathrm{CO}_{2}$ and $95 \%$ air in culture medium supplemented with $5 \%$ FBS, until growing BOEC monolayer was covered up to $70-80 \%$ of the bottom of the culture plate.

The average time taken for BOEC to form a monolayer was 5 days. The average cell concentration at the end of the experiment was $8 \times 10^{4}$ cells $/ \mathrm{ml}$. The characterization of bovine OEC was conducted based on a previous report (Rosselli et al. 1994). Briefly, cell viability was assessed in control and treated cells with Trypan blue staining and confirmed to be more than $90 \%$ viable at the time of plating, as well as at the end of the experiment. The purity of epithelial cell preparations was evaluated by reacting the cultured cells with monoclonal antibodies to cytokeratin (anti-cytokeratin, CK1) and immunostaining. The cells in culture showed characteristic epithelial morphology. Approximately $98 \%$ of the cells stained positively for CK1 antibodies.

\section{Preparation of spermatozoa}

\section{Capacitation}

Capacitation was achieved using Tyrode's albumin, lactate, and pyruvate medium (sp-TALP), as previously described (Parrish et al. 1988, 1989), with little modification. In brief, frozen thawed semen from five bulls were pooled and diluted with $5 \mathrm{ml}$ conditioned sp-TALP. Following 1 -h swim up at $38.5^{\circ} \mathrm{C}$ and $5 \% \mathrm{CO}_{2}$ in air, the supernatant was recovered, pooled, and centrifuged at $350 \mathrm{~g}$ for $5 \mathrm{~min}$. Then, the preparation was re-suspended in $1 \mathrm{ml} \mathrm{sp-TALP}$ and the concentration of the spermatozoa was calculated using a hemocytometer. Nigrosin-eosin staining was performed to evaluate the livability of spermatozoa, and more than $85 \%$ of live spermatozoa were obtained from the samples. Progressive motility was subjectively assessed by visual examination under a light microscope equipped with a stage warmer. These swim-up spermatozoa were used in the subsequent experiments.

\section{Heat inactivation and decapitation of spermatozoa}

Swim-up spermatozoa were subjected to heat inactivation in a water bath at $55^{\circ} \mathrm{C}$ for $30 \mathrm{~min}$ to obtain dead spermatozoa. Immobilization was confirmed by subjective visual observation of samples under light microscope. Decapitation of spermatozoa was conducted as described previously (Kuretake et al. 1996, Tateno et al. 2000) with little modification. Briefly, a $15 \mathrm{ml}$ Falcon tube (Nalge Nunc International) containing $7 \mathrm{ml}$ swim-up spermatozoa suspension was placed on iced water, and the suspension was 'lightly' sonicated at $60 \%$ power output for $5 \mathrm{~s}$ using a $10 \mathrm{~mm}$ diameter horn (Sonics Vibra Cell, Sonics and Materials Inc., New town, CT, USA). The viability of decapitated spermatozoa was assessed by the eosin-nigrosin staining technique and confirmed to be more than $80 \%$.

Experiment 1: dose-dependent effect of spermatozoa on release of $P G$ from $B O E C$

Sub-confluent BOEC monolayers in the second passage were pre-incubated for $1 \mathrm{~h}$ in co-culture medium (TCM 199; HEPES modification; $0.85 \mathrm{~g} / \mathrm{l} \mathrm{NaHCO}_{3}, 60 \mathrm{mg} / \mathrm{l}$ penicillin, $100 \mathrm{mg} / \mathrm{l}$ streptomycin, and $56 \mathrm{mg} / \mathrm{l}$ ascorbic acid; Sigma Chemicals Co.) supplemented with $1 \%$ BSA, insulin $(5 \mathrm{mg} / \mathrm{l})$, transferrin $(5 \mathrm{mg} / \mathrm{l})$, and sodium selenite $(5 \mu \mathrm{g} / \mathrm{l})$. After pre-incubation, BOEC monolayers were co-cultured with four doses of $\left(10^{3}-10^{6}\right.$ spermatozoa $/ \mathrm{ml}$ ) capacitated spermatozoa and $10^{5}$ 'dead' spermatozoa/ml for $12 \mathrm{~h}$ at $38.5^{\circ} \mathrm{C}$ in $5 \% \mathrm{CO}_{2}$ in air $(n=7$ for each treatment). The BOEC monolayers 
without spermatozoa and spermatozoa in co-culture medium without BOEC served as positive and negative controls respectively. An additional volume of sp-TALP was added to controls in order to control for any potential effect of the sp-TALP that was added with spermatozoa during the incubation.

\section{Experiment 2: time-dependent effect of the spermatozoa} on release of $P G$ from $B O E C$

Based on the dose-dependent study (Experiment 1), a spermatozoa dose of $10^{5}$ was used to evaluate the timedependent effect of the spermatozoa on release of PG from BOEC. Sub-confluent BOEC monolayers in the second passage were pre-incubated in culture medium for $1 \mathrm{~h}$, then co-cultured with $10^{5}$ spermatozoa/ml for $1,3,12$, and $24 \mathrm{~h}$ ( $n=7$ for each treatment) at $38.5^{\circ} \mathrm{C}$ in $5 \% \mathrm{CO}_{2}$ in air. The BOEC monolayer without spermatozoa served as the control.

Experiment 3: effect of the motile, dead, and decapitated spermatozoa on release of $P G$ from $B O E C$

Sub-confluent BOEC monolayers in the second passage were pre-incubated in culture medium for $1 \mathrm{~h}$ and co-cultured with motile, dead, or decapitated spermatozoa at a dose of $10^{5}$ spermatozoa/ml for $12 \mathrm{~h}(n=7$ for each treatment) at $38.5{ }^{\circ} \mathrm{C}$ in $5 \% \mathrm{CO}_{2}$ in air. A BOEC monolayer without spermatozoa served as the control.

\section{Cell preparation}

After the desired period of incubation, the medium was collected from each well of six-well culture dishes and pooled. Cells in all six wells in a plate were trypsinized, washed twice with $15 \mathrm{ml} 0.01 \mathrm{M}$ PBS (PBS (-); pH 7.4; Sigma Chemicals Co.), and re-suspended in $6 \mathrm{ml} \mathrm{PBS}(-)$. A $50 \mu \mathrm{l}$ portion of the cell suspension was used to evaluate the cell concentration. The remaining cells were again separated by centrifugation $\left(300 \mathrm{~g}\right.$ for $10 \mathrm{~min}$ at $\left.4{ }^{\circ} \mathrm{C}\right)$, lysed with SV RNA Lysis Buffer (Promega Corporation), and stored at $-80{ }^{\circ} \mathrm{C}$ until the RNA extraction.

\section{Measurements of PG}

The medium was centrifuged ( $300 \mathrm{~g}$ for $10 \mathrm{~min}$ at $4{ }^{\circ} \mathrm{C}$ ) to remove any spermatozoa, and the subsequent spermfree medium was used for performing enzyme immunoassays for $\mathrm{PGE}_{2}$ and $\mathrm{PGF}_{2 \alpha}$. The assays were performed according to Miyamoto et al. (1995) and Wijayagunawardane et al. (1998) respectively. For $\mathrm{PGE}_{2}$, withinassay and between-assay coefficients of variance (CV values) were 7.3 and $11.4 \%$ respectively. For $\mathrm{PGF}_{2 \alpha,}$ within-assay and between-assay CV were 8.2 and $11.8 \%$. The ED50 for the $\mathrm{PGE}_{2}$ and $\mathrm{PGF}_{2 \alpha}$ assays were 260 and $355 \mathrm{pg} / \mathrm{ml}$, and the ranges of the standard curves for these assays were 20-20000 and $10-10000 \mathrm{pg} / \mathrm{ml}$ respectively.

\section{RNA extraction, CDNA synthesis, and real-time RT-PCR}

RNA extraction from collected cells, cDNA synthesis, and real-time RT-PCR were conducted as previously described (Wijayagunawardane et al. 2005). Total RNA was extracted using the SV Total RNA Isolation System (Promega Corporation) according to the manufacturer's protocol. In the final step of SV Total RNA Isolation System, a DNase treatment was included to exclude residual genomic DNA or other contaminations. RNA concentration was measured using Bio-Tech Photometer (WPA, Cambridge, UK) at $260 \mathrm{~nm}$ absorbance and the concentration was adjusted to be $1 \mu \mathrm{g} / \mu \mathrm{l}$. The extracted total RNA was stored in RNA storage solution (Ambion, Austin, Texas, USA) at $-30{ }^{\circ} \mathrm{C}$ until used for cDNA synthesis.

First strand cDNA synthesis was conducted according to a commercial protocol described in SuperScript II Reverse Transcriptase (Invitrogen Corp). The first cocktail was prepared using $2 \mu \mathrm{g}$ total RNA, $150 \mathrm{ng}$ random primer (Invitrogen), $0.83 \mathrm{mM}$ PCR Nucleotide Mix (dNTP; Roche Diagnostic Corp.), and $\mathrm{H}_{2} \mathrm{O}$, making the final volume of $12 \mu \mathrm{l} /$ tube, subsequently incubated at $65{ }^{\circ} \mathrm{C}$ for $5 \mathrm{~min}$ in a thermal cycler (Mastercycler, Eppendorf, Netheler Hinz GmbH, Hamburg, Germany). The samples were kept on ice and $7 \mu$ second cocktail; $0.01 \mathrm{M}$ dithiothreitol (Invitrogen), 60 units of RNase inhibitor (RNasin, Promega), and First Strand Buffer (Invitrogen)/tube were added. Then, the samples were again incubated for $2 \mathrm{~min}$ at $42{ }^{\circ} \mathrm{C}$ and 200 units SuperScript II Reverse Transcriptase in $1 \mu \mathrm{l} /$ tube were added. The thermal cycle program was run at $25^{\circ} \mathrm{C}$ for $10 \mathrm{~min}, 42^{\circ} \mathrm{C}$ for $50 \mathrm{~min}$, and finally $75^{\circ} \mathrm{C}$ for $15 \mathrm{~min}$. The synthesized cDNA was stored at $-30^{\circ} \mathrm{C}$.

The real-time RT-PCR (LightCycler; Roche diagnostics) and LightCycler-FastStart DNA Master SYBR Green 1 commercial kit (Roche) with commercially synthesized primers (Hokkaido System Science Co. Ltd, Sapporo, Japan; Table 1) were used to amplify each specific bovine transcript. Each capillary (Roche) contained $2 \mu \mathrm{l}$ cDNA, $2 \mu \mathrm{l}$ LightCycler-FastStart Reaction Mix SYBR Green 1 with LightCycler-FastStart Enzyme, $2.5 \mathrm{mM} \mathrm{MgCl} 2,0.5 \mu \mathrm{M}$ of each forward and reverse primers, and $14.8 \mu \mathrm{l} \mathrm{H}_{2} \mathrm{O}$; making the final volume of $20 \mu \mathrm{l} /$ capillary. A negative control, which was prepared by replacing CDNA with PCR-grade water in the above mixture, was included in each run. The capillaries were centrifuged in LightCycler Carousal Centrifuge (Roche) before the amplification. The amplification was done with an initial denaturation at $95^{\circ} \mathrm{C}$ for $10 \mathrm{~min}$, followed by 40 cycles of denaturation at $95^{\circ} \mathrm{C}$ for $10 \mathrm{~s}$, annealing at $65^{\circ} \mathrm{C}$ for $10 \mathrm{~s}$, and the extension at $72{ }^{\circ} \mathrm{C}$ for $20 \mathrm{~s}$. Finally, cooling was done at $30{ }^{\circ} \mathrm{C}$. The melting curve was obtained from 70 to $95^{\circ} \mathrm{C}$ at the rate of $0.1^{\circ} \mathrm{C} / \mathrm{s}$.

For the quantification of each target gene, a DNA standard was constructed by amplifying a fragment of 
Table 1 Primers used to amplify specific bovine transcripts.

\begin{tabular}{|c|c|c|c|}
\hline Ligand & Primer & Sequence (position in cDNA) & Fragment size $(b p)$ \\
\hline \multirow[t]{2}{*}{ COX-2 } & Forward & 5'-TCCTGAAACCCACTCCCAACA-3' (137-157) & \multirow[t]{2}{*}{242} \\
\hline & Reverse & 5'-TGGGCAGTCATCAGGCACAG-3' (359-379) & \\
\hline \multirow[t]{2}{*}{ PGES } & Forward & 5'-CGCTGCTGGTCATCAAAAT-3' (73-90) & \multirow[t]{2}{*}{186} \\
\hline & Reverse & 5'-GGAAGGGGTAGATGGTCTCC-3' (238-259) & \\
\hline \multirow[t]{2}{*}{ PGFS } & Forward & 5'-GATGGCCACTTCATTCCTGT-3' (34-53) & \multirow[t]{2}{*}{195} \\
\hline & Reverse & 5'-CACAGTGCCATCTGCAATCT-3' (208-229) & \\
\hline \multirow[t]{2}{*}{$\beta$-actin } & Forward & 5'-CCAAGGCCAACCGTGAGAAGAT-3' (374-395) & \multirow[t]{2}{*}{256} \\
\hline & Reverse & 5'-CCACGTTCCGTGAGGATCTTCA-3' (608-629) & \\
\hline
\end{tabular}

DNA ( 700 bp), which contained target sequence for quantitative PCR $(100 \sim 150 \mathrm{bp})$. The PCR products were subjected to electrophoresis; the target band was cut out and purified using a DNA purification kit (SUPRECTM-01; TaKaRa Bio Inc., Otsu, Japan). Three to five stepwise-diluted DNA standards were included in each PCR run. The quantification of mRNA expression was done using LightCycler Software (Version 3.5; Roche). The values were normalized using $\beta$-actin as the internal standard using delta-delta Ct method (Pfaffl 2001) and expressed as the percentage of control values.

\section{Experimental design and statistical analysis}

All experiments were carried out under the standard laboratory conditions with completely randomized design, keeping the controls for every treatment group concerned. The data on dose- and time-dependent effect of spermatozoa on PG release by BOEC as well as the effect of live, dead, and decapitated spermatozoa on PG biosynthesis and release were analyzed using one-way ANOVA followed by Tukey-Kramer test. Data on timedependent effect of the PG production at each time point was separately analyzed using the simple paired $t$-test, followed by the F-test.

The mRNA expression values for cyclooxygenase-2 (COX-2), PGES, and PGFS were compared with the control values using ANOVA followed by the TukeyKramer test for the mean separation. The data were subjected to the arcsine transformation before the statistical analysis. $P<0.05$ were considered as significant.

\section{Results}

Within $1 \mathrm{~h}$ of co-incubation, almost all the surviving spermatozoa were observed to be bound to the BOEC monolayer. The spermatozoa that were bound to BOEC showed $80 \%$ viability after $24-\mathrm{h}$ experimental period. The capacitated spermatozoa that were added to the medium without BOEC were observed to be dead after $3 \mathrm{~h}$ of incubation.

\section{Experiment 1: effect of different doses of capacitated spermatozoa on the release of PG by BOEC monolayer}

The spermatozoa dose dependently increased the release of both $\mathrm{PGF}_{2 \alpha}$ and $\mathrm{PGE}_{2}$ from the BOEC (Fig. 1). When compared with controls, incubation of BOEC with spermatozoa $10^{4}, 10^{5}$, and $10^{6} \mathrm{ml}$ for $12 \mathrm{~h}$ significantly increased $(P<0.05-0.005)$ the $\mathrm{PGE}_{2}$ release to the medium (Fig. 1a). Compared with the controls, $10^{5}$ and $10^{6}$ spermatozoa/ml showed a significant increase in the release of $\mathrm{PGF}_{2 \alpha}(P<0.01$; Fig. $1 \mathrm{~b})$. Dead spermatozoa did not show any significant change in the release of PG. The intensity of PG release with $10^{5}$ spermatozoa/ml was not significantly different from the dose of $10^{6} \mathrm{spermatozoa} / \mathrm{ml}$. In this series of
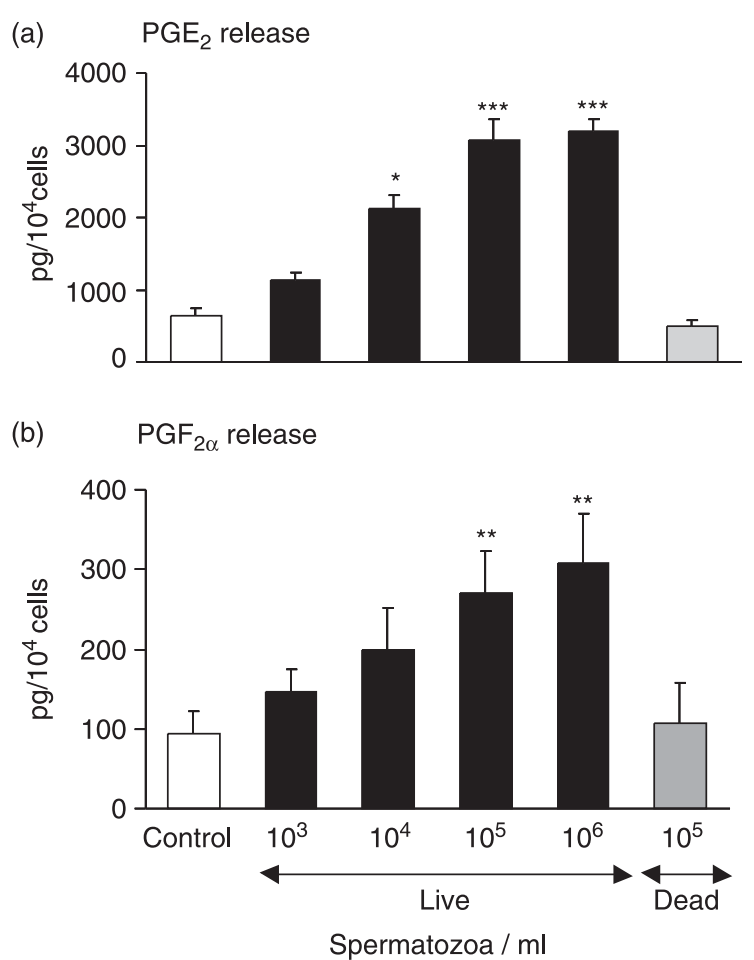

Figure 1 Dose-dependent response of capacitated spermatozoa on (a) $\mathrm{PGE}_{2}$ and (b) $\mathrm{PGF}_{2 \alpha}$ release (mean \pm S.E.M.) by oviduct epithelial cell (BOEC) monolayers after $12 \mathrm{~h}$ of co-culture $(n=7) .{ }^{*} P<0.05$, ** $P<0.01, * * P<0.005$. 
experiments, $10^{5}$ spermatozoa $/ \mathrm{ml}$ was identified as the most effective dose for the PG release by BOEC.

\section{Experiment 2: time-dependent effect of the $P G$ release due to the stimulation of motile spermatozoa}

Spermatozoa time dependently increased the release of both $\mathrm{PGF}_{2 \alpha}$ and $\mathrm{PGE}_{2}$ from the BOEC (Fig. 2). The timedependent data for $\mathrm{PGE}_{2}$ showed that 6, 12 as well as $24-\mathrm{h}$ co-incubation of spermatozoa with BOEC significantly stimulated $(P<0.01-0.005) \quad \mathrm{PGE}_{2}$ release, when compared with controls (Fig. 2a). When compared with 6-h co-incubation, 12 - and 24-h co-incubation resulted in a higher $(P<0.05)$ release of $\mathrm{PGE}_{2}$ (Fig. 2b). However, the $\mathrm{PGE}_{2}$ release between 12 - and $24-\mathrm{h}$ co-incubation was not significantly different. Only $12-$ and 24-h co-incubation showed a significant increase in $\mathrm{PGF}_{2 \alpha}$ release when compared with the control $(P<0.01-0.05)$. There was no significant difference in the intensity of $P G$ release between 12 and $24 \mathrm{~h}$ upon co-incubation. Therefore, 12-h incubation period was identified as the most effective time period of incubation for the PG release by BOEC. Dead spermatozoa did not show any significant change in the release of PG

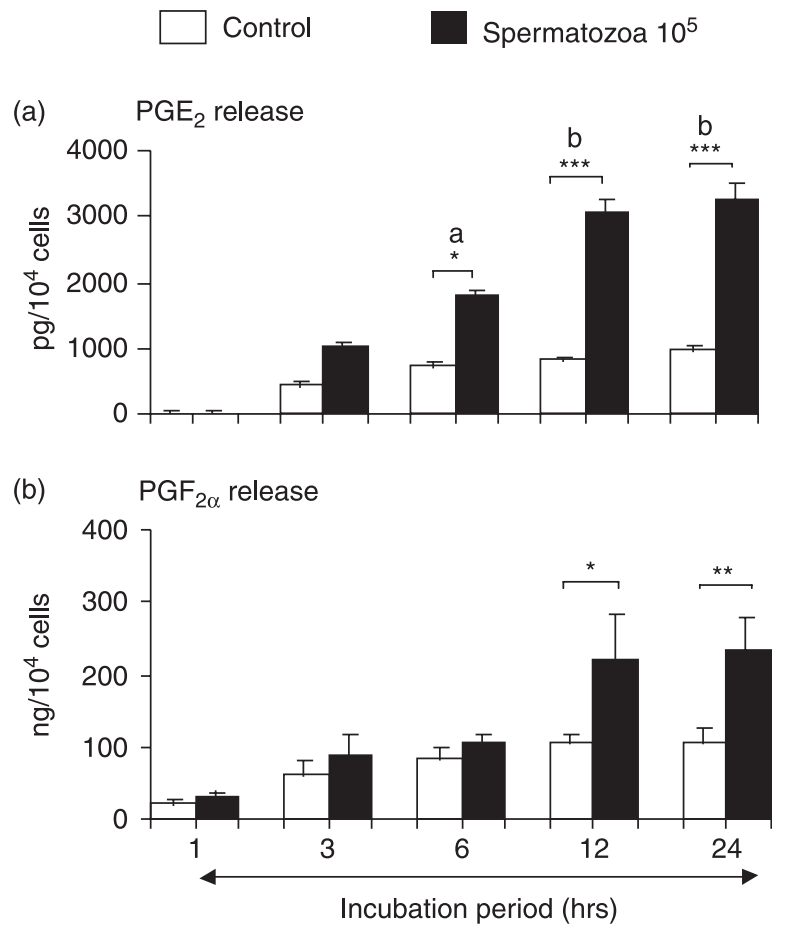

Figure 2 Time-dependent effect of capacitated spermatozoa $\left(10^{5} \mathrm{ml}\right)$ on (a) $\mathrm{PGE}_{2}$ and (b) $\mathrm{PGF}_{2 \alpha}$ release (mean \pm s.E.M.) by bovine oviduct epithelial cell (BOEC) monolayers after $12 \mathrm{~h}$ of co-culture $(n=7)$. ${ }^{*} P<0.05,{ }^{* *} P<0.01,{ }^{* * *} P<0.005 .{ }^{\mathrm{ab}}$ Different letters denote a significant difference at $P<0.05$.

\section{Experiment 3: $P G$ release and $m R N A$ expression in BOEC}

Only live spermatozoa showed a significant effect on the release of PGs from BOEC, whereas dead or decapitated spermatozoa had no significant effect on the secretion of PG by BOEC. Capacitated live spermatozoa added to BOEC up-regulated $(P<0.01-0.005)$ mRNA expression for COX-2, PGES as well as PGFS. Neither dead nor decapitated spermatozoa caused a significant level of mRNA expression for the COX-2 (Fig. 3a), PGES (Fig. 3b), and PGFS (Fig. 3c).

\section{Discussion}

The results of the present study provide the first direct evidence that live motile spermatozoa stimulate biosynthesis and secretion of $\mathrm{PGE}_{2}$ and $\mathrm{PGF}_{2 \alpha}$ in the cow oviduct in vitro. These eicosanoids play a major role in oviductal motility by causing oviductal smooth muscle cells to contract and relax rhythmically, facilitating the spermatozoa transportation to the site of fertilization (Harper et al. 1980, Harper 1994). In the present study, only motile capacitated spermatozoa caused a significant increase in the expression of mRNA for COX-2, PGES, and PGFS along with the secretions of $\mathrm{PGE}_{2}$ and $\mathrm{PGF}_{2 \alpha}$ by the BOEC. Dead or live spermatozoa heads did not show any effect on PG biosynthesis and secretion by BOEC. This phenomenon suggests that a mechanical stimulation of BOEC with the binding of motile spermatozoa may stimulate the PG system in the bovine oviduct. The ability of spermatozoa to induce gene expression in oviductal cells may involve a signal transduction mechanism, which is complex and involves several ligands from the sperm side that become activated after sperm binding to oviduct. We speculate that dead spermatozoa or sperm head alone are unable to present the appropriate ligands to achieve stimulation of oviductal cells.

In ruminants, $\mathrm{PGF}_{2 \alpha}$ and $\mathrm{PGE}_{2}$ are the primary PGs produced in the female reproductive tract (Desnoyers et al. 1995), and in the cow oviduct, the levels of $\mathrm{PGF}_{2 \alpha}$ and $\mathrm{PGE}_{2}$ were found to be higher during the periovulatory period of the estrus cycle (Wijayagunawardane et al. 1998). In the bovine endometrium, the PG synthesis is mainly governed by the rate-limiting enzyme COX-2, which converts arachidonic acid to the precursor $\mathrm{PGH}_{2}$, where it is further converted to $\mathrm{PGE}_{2}$ and $\mathrm{PGF}_{2 \alpha}$ by the key downstream enzymes of PGES and PGFS (Arosh et al. 2002, 2003, 2004a, 2004b). In the present study, it was observed that co-incubation of BOEC with spermatozoa significantly increased the mRNA expression for COX-2, PGES, and PGFS. This spermatozoa-oviductal interaction may be mediated by binding of the spermatozoa to the epithelium and at least, in part, due to the mechanical stimulation entrusted on the BOEC. Additionally, already identified 

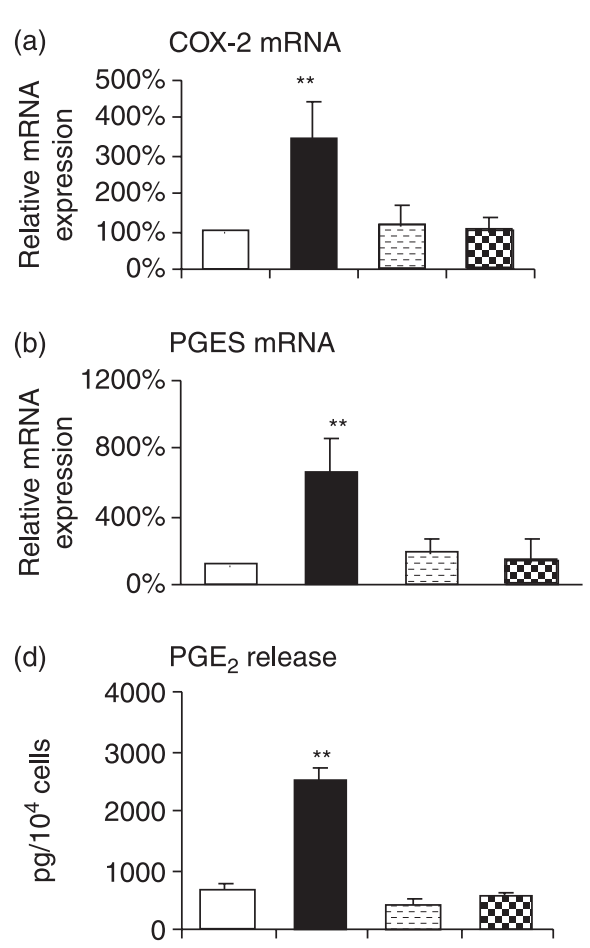

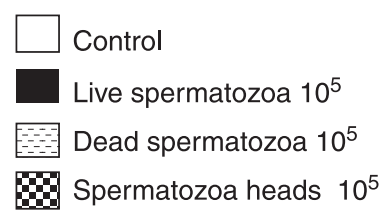

(c) PGFS mRNA

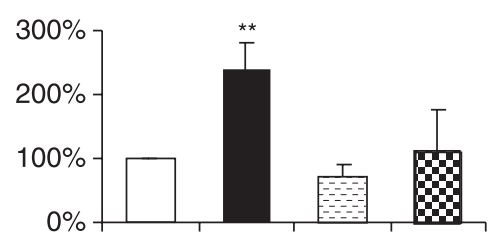

(e)

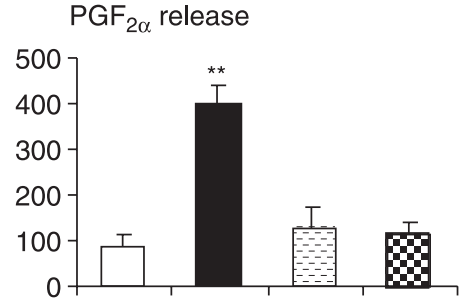

Figure 3 Effect of live, dead, and decapitated spermatozoa $\left(10^{5} \mathrm{ml}\right)$ on the mRNA expression of (a) COX-2, (b) PGES, (c) PGFS in $\mathrm{BOEC}$, (d) $\mathrm{PGE}_{2}$ release, and (e) $\mathrm{PGF}_{2 \alpha}$ release by bovine oviduct epithelial cell (BOEC) at 12-h co-culture $(n=7) .{ }^{* *} P<0.01$, $* * * P<0.005$. factors (Boilard et al. 2004, Ekhlasi-Hundrieser et al. 2005, Quintero et al. 2005), as well as numerous unidentified factors that may be secreted by live spermatozoa, can also be involved in this process (Quintero et al. 2005). However, a detail mechanism of cell-to-cell communication between spermatozoa and BOEC, which enhances biosynthesis and secretion of PG from the oviduct, awaits further investigation.

According to previous reports, capacitated spermatozoa have the ability to induce de novo protein synthesis and secretion within the cow oviduct, which creates an optimum microenvironment for the survival of gametes (Ellington et al. 1993). It was observed that the attachment of spermatozoa to the BOEC monolayer increased intracellular $\mathrm{Ca}^{++}$levels, and this appears to enhance a cell-to-cell communication (Ellington et al. 1993). Therefore, calcium may be a potential candidate in mediating the cell-to-cell communication. A study on the mouse oviduct has revealed a system of spermatozoa recognition via a signal transduction pathway leading to a change in the oviductal gene expression profile (Fazeli et al. 2004).

Two separate studies on the gene expressions in the bovine oviduct using a combination of subtracted cDNA libraries and CDNA array hybridization (Bauersachs et al. 2003, 2004) give further evidence of complex mechanisms existing in the oviduct at molecular level, where alterations of differential gene expression in the different segments of the bovine oviduct directly alter the production of numerous cell-surface proteins, cell-cell interaction proteins, members of signal transduction pathways, immune-related proteins, and enzymes. These factors could also be the potential candidates involved in the spermatozoa-oviduct cross communication to enhance the biosynthesis of epithelial cell-borne bioactive substances in the bovine oviduct, and thus, would be a topic to be followed in future investigations.

Even though spermatozoa come into contact with cervical and uterine epithelia, the interaction with oviductal epithelium is unique due to the formation of oviductal-spermatozoa reservoir (Suarez et al. 1997). This reservoir acts to ensure the availability of sufficient viable spermatozoa for the capacitation and the survival of spermatozoa until fertilization (Lefebvre et al. 1997). In the present study, within $1 \mathrm{~h}$ of co-incubation, almost all the surviving spermatozoa were observed to be bound to the BOEC monolayer. Furthermore, the added dose of $10^{4}$ spermatozoa $/ \mathrm{ml}$ showed a significant effect on biosynthesis and secretion of PG. These observations suggest that spermatozoa physiologically or/and physically interact with oviductal epithelium to alter the local oviductal environment more favorable for its own function.

In our previous studies, we have shown that vasoactive peptides such as Ang II and ANP (Wijayagunawardane et al. 2001a), ET-1 (Wijayagunawardane \& Miyamoto 2004a), together with VEGF (Wijayagunawardane et al. 2005) and LH (Wijayagunawardane et al. 2001b), stimulated PG secretion in the bovine oviduct during the periovulatory period. Moreover, the periovulatory $\mathrm{LH}$ surge with the basal level of $\mathrm{P}_{4}$ from the regressing $C L$, together with the high level of $E_{2}$ from the Graafian follicle, have been shown to have a significant increase in PG release by the BOEC in vitro (Wijayagunawardane 
et al. 2001 b). Most importantly, PG, LH, ET-1 Ang II, and ANP directly stimulate the oviductal contraction (Wijayagunawardane et al. 2001a). In the present study, spermatozoa stimulate PG biosynthesis and secretion. Thus, during the periovulatory period, spermatozoa may stimulate oviductal motility through the elevation of local PG levels facilitating their timely transportation to the fertilization site. Interestingly, the maximum effective level of PG release was observed after $12 \mathrm{~h}$ of incubation, and this may be correlated with the timing of ovulation to assure the optimum number of spermatozoa at the site of fertilization.

In conclusion, the findings of the present study demonstrate for the first time that motile spermatozoa trigger PG biosynthesis and secretion in the cow oviduct. Elevated levels of PG may enhance oviductal motility to facilitate the timely transportation of spermatozoa to the site of fertilization.

\section{Acknowledgements}

The authors wish to thank Dr S Ito, Kansai University, Japan for PG antiserum, Dr S Matsuzaki, Genetics Hokkaido Association, Hokkaido, Japan for providing bull spermatozoa, and Ms S Ikumi for technical assistance. The authors specially acknowledge Dr A Stephen Georgiou, Academic Unit of Reproductive and Developmental Medicine, University of Sheffield, UK for constructive criticisms to improve the manuscript. This study was supported by the National Research Council of Sri Lanka (Grant 05-26) and the 21st Century COE Program (A-1), the Ministry of Education, Culture, Science and Technology, Japan. The authors declare that there is no conflict of interest that would prejudice the impartiality of this scientific work.

\section{References}

Abe H, Sendai Y, Satoh T \& Hoshi H 1995 Bovine oviduct-specific glycoprotein: a potent factor for maintenance of viability and motility of bovine spermatozoa in vitro. Molecular Reproduction and Development 42 226-232.

Arosh JA, Parent J, Chapdelaine P, Sirois J \& Fortier MA 2002 Expression of cyclooxygenases 1 and 2 and prostaglandin E synthase in bovine endometrial tissue during the estrous cycle. Biology of Reproduction 67 161-169.

Arosh JA, Banu SK, Chapdelaine P, Emond V, Kim JJ, MacLaren LA \& Fortier MA 2003 Molecular cloning and characterization of bovine prostaglandin $\mathrm{E}_{2}$ receptors $\mathrm{EP}_{2}$ and $\mathrm{EP}_{4}$ : expression and regulation in endometrium and myometrium during the estrous cycle and early pregnancy. Endocrinology 144 3076-3091.

Arosh JA, Banu SK, Chapdelaine P \& Fortier MA 2004a Temporal and tissue-specific expression of prostaglandin receptors $\mathrm{EP}_{2}, \mathrm{EP}_{3}, \mathrm{EP}_{4}$, $\mathrm{FP}$, and cyclooxygenases 1 and 2 in uterus and fetal membranes during bovine pregnancy. Endocrinology 145 407-417.

Arosh JA, Banu SK, Kimmins S, Chapdelaine P, Maclaren LA \& Fortier MA 2004b Effect of interferon-tau on prostaglandin biosynthesis, transport, and signaling at the time of maternal recognition of pregnancy in cattle: evidence of polycrine actions of prostaglandin $\mathrm{E}_{2}$. Endocrinology 145 5280-5293.
Bauersachs S, Blum H, Mallok S, Wenigerkind H, Rief S, Prelle K \& Wolf E 2003 Regulation of ipsilateral and contralateral bovine oviduct epithelial cell function in the postovulation period: a transcriptomics approach. Biology of Reproduction 68 1170-1177.

Bauersachs S, Rehfeld S, Ulbrich SE, Mallok S, Prelle K, Wenigerkind H, Einspanier R, Blum H \& Wolf E 2004 Monitoring gene expression changes in bovine oviduct epithelial cells during the oestrous cycle. Journal of Molecular Endocrinology 32 449-466.

Boatman DE 1997 Responses of gametes to the oviductal environment. Human Reproduction 12 133-149.

Boilard M, Reyes-Moreno C, Lachance C, Massicotte L, Bailey JL, Sirard MA \& Leclerc P 2004 Localization of the chaperone proteins GRP78 and HSP60 on the luminal surface of bovine oviduct epithelial cells and their association with spermatozoa. Biology of Reproduction 71 1879-1889.

Desnoyers G, Meyer M, Gross T, Johnson J \& Thatcher W 1995 Regulation of endometrial prostaglandin synthesis during earlypregnancy in cattle: effects of phospholipases and calcium in vitro. Prostaglandins 50 313-330.

Ekhlasi-Hundrieser M, Gohr K, Wagner A, Tsolova M, Petrunkina A \& Topfer-Petersen E 2005 Spermadhesin AQN1 is a candidate receptor molecule involved in the formation of the oviductal sperm reservoir in the pig. Biology of Reproduction 73 536-545.

Ellington JE 1991 The bovine oviduct and its role in reproduction: a review of the literature. Cornell Veterinarian 81 313-328.

Ellington JE, Ignotz GG, Ball BA, Meyers-Wallen VN \& Currie WB 1993 De novo protein synthesis by bovine uterine tube (oviduct) epithelial cells changes during co-culture with bull spermatozoa. Biology of Reproduction 48 851-856.

Fazeli A, Duncan AE, Watson PF \& Holt WV 1999 Sperm-oviduct interaction: induction of capacitation and preferential binding of uncapacitated spermatozoa to oviductal epithelial cells in porcine species. Biology of Reproduction 60 879-886.

Fazeli A, Affara NA, Hubank M \& Holt WV 2004 Sperm-induced modification of the oviductal gene expression profile after natural insemination in mice. Biology of Reproduction 71 60-65.

Georgiou AS, Sostaric E, Wong CH, Snijders AP, Wright PC, Moore HD \& Fazeli A 2005 Gametes alter the oviductal secretory proteome. Molecular and Cellular Proteomics 4 1785-1796.

Harper M 1994 The biology of reproduction. In Gamete and ZygoteTransportation, 2 edn, pp 123-187. Eds E Knobil \& JD Neil. New York: Raven Press.

Harper M, Coons L, Radicke D, Hodgson B \& Valenzuela G 1980 Role of prostaglandins in contractile activity of the ampulla of the rabbit oviduct. American Journal of Physiology 238 E157-E166.

Killian GJ 2004 Evidence for the role of oviduct secretions in sperm function, fertilization and embryo development. Animal Reproduction Science 82-83 141-153.

Kuretake S, Kimura Y, Hoshi K \& Yanagimachi R 1996 Fertilization and development of mouse oocytes injected with isolated sperm heads. Biology of Reproduction 55 789-795.

Lefebvre R, Lo MC \& Suarez SS 1997 Bovine sperm binding to oviductal epithelium involves fucose recognition. Biology of Reproduction 56 1198-1204.

McNutt TL \& Killian GJ 1991 Influence of bovine follicular and oviduct fluids on sperm capacitation in vitro. Journal of Andrology 12 244-252.

Miyamoto A, Tashiro Y, Nakatsuka T, Meyer H, Taguchi K, Abe N \& Fukui Y 1995 Effect of tumor necrosis factor alpha and Interleukin-1 on local release of progestrone, prostaglandin F2alpha and oxytocin inmicrodialized ovine corpus luteum in vitro. Assisted Reproductive Technology/Andrology 8 21-32.

Parrish JJ, Susko-Parrish J, Winer MA \& First NL 1988 Capacitation of bovine sperm by heparin. Biology of Reproduction 38 1171-1180.

Parrish JJ, Susko-Parrish JL, Handrow RR, Sims MM \& First NL 1989 Capacitation of bovine spermatozoa by oviduct fluid. Biology of Reproduction 40 1020-1025. 
Pfaffl MW 2001 A new mathematical model for relative quantification of in real-time RT-PCR. Nucleic Acid Research 201 2002-2007.

Quintero I, Ghersevich S, Caille A, Munuce MJ, Daniele SM \& Morisoli L 2005 Effects of human oviductal in vitro secretion on spermatozoa and search of sperm-oviductal proteins interactions. International Journal of Andrology 28 137-143.

Rosselli M, Imthurn B, Macas E \& Keller PJ 1994 Endothelin production by bovine oviduct epithelial cells. Journal of Reproduction and Fertility 101 27-30.

Suarez SS, Brockman K \& Lefebvre R 1997 Distribution of mucus and sperm in bovine oviducts after artificial insemination: the physical environment of the oviductal sperm reservoir. Biology of Reproduction 56 447-453.

Tateno H, Kimura Y \& Yanagimachi R 2000 Sonication per se is not as deleterious to sperm chromosomes as previously inferred. Biology of Reproduction 63 341-346.

Wijayagunawardane M \& Miyamoto A 2004a Endothelin-1 system in the bovine oviduct: a regulator of local contraction and gamete transport. Journal of Cardiovascular Pharmacology 44 (Suppl 1) S248-S251.

Wijayagunawardane MP \& Miyamoto A 2004b Tumor necrosis factor alpha system in the bovine oviduct: a possible mechanism for embryo transport. Journal of Reproduction and Development 50 57-62.

Wijayagunawardane M, Miyamoto A, Cerbito W, Acosta T, Takagi M \& Sato K 1998 Local distributions of oviductal estradiol, progesterone, prostaglandins, oxytocin and endothelin-1 in the cyclic cow. Theriogenology 49 607-618.

Wijayagunawardane MP, Choi YH, Miyamoto A, Kamishita H, Fujimoto S, Takagi M \& Sato K 1999a Effect of ovarian steroids and oxytocin on the production of prostaglandin $E_{2}$, prostaglandin F2alpha and endothelin-1 from cow oviductal epithelial cell monolayers in vitro. Animal Reproduction Science 56 11-17.
Wijayagunawardane MP, Miyamoto A \& Sato K $1999 \mathrm{~b}$ Prostaglandin $\mathrm{E}_{2}$, prostaglandin $\mathrm{F} 2$ alpha and endothelin-1 production by cow oviductal epithelial cell monolayers: effect of progesterone, estradiol $17 \beta$, oxytocin and luteinizing hormone. Theriogenology $\mathbf{5 2}$ 791-801.

Wijayagunawardane MP, Miyamoto A, Taquahashi Y, Acosta TJ, Nishimura M \& Sato K 2001a Angiotensin II and atrial natriuretic peptide in the cow oviductal contraction in vitro: direct effect and local secretion of prostaglandins, endothelin-1, and angiotensin II. Biology of Reproduction 65 799-804.

Wijayagunawardane MP, Miyamoto A, Taquahashi Y, Gabler C, Acosta TJ, Nishimura M, Killian G \& Sato K $2001 b$ In vitro regulation of local secretion and contraction of the bovine oviduct: stimulation by luteinizing hormone, endothelin-1 and prostaglandins, and inhibition by oxytocin. Journal of Endocrinology 168 117-130.

Wijayagunawardane MPB, Gabler C, Killian G \& Miyamoto A 2003 Tumor necrosis factor $\alpha$ in the bovine oviduct during the estrous cycle: messenger RNA expression and effect on secretion of prostaglandins, endothelin-1, and angiotensin II. Biology of Reproduction 69 1341-1346.

Wijayagunawardane M, Kodithuwakku S, Yamamoto D \& Miyamoto A 2005 Vascular endothelial growth factor system in the cow oviduct: a possible involvement in the regulation of oviductal motility and embryo transport. Molecular Reproduction and Development $\mathbf{7 2}$ 511-520.

Received 10 September 2006

First decision 27 September 2006

Revised manuscript received 7 March 2007

Accepted 15 March 2007 